\title{
Nutrient Composition of Aerobic Rice as Influenced by Different Sources and Levels of Sulphur Application
}

\author{
N.R. Sudhakara*, N. Srinivasa and R. Krishnamurthy \\ Department of Soil Science and Agricultural Chemistry, College of agriculture, \\ University of Agricultural Sciences, GKVK, Banglore- 560 065, Karnataka, India \\ *Corresponding author
}

\section{A B S T R A C T}

\section{Keywords}

Aerobic rice, Sulphur sources, Sulphur levels and Nutrient composition

Article Info

Accepted:

17 November 2018

Available Online:

10 December 2018
A field experiment was carried out during the Kharif season of 2015, with the objective to study the effect of different sources and levels of sulphur application on nutrient composition of aerobic rice (Oryza sativa L.) cv. Rashi. In the effect among sources of sulphur, Ammonium sulphate had a significant influence and relatively better than other sources. As regards to levels the highest nutrient composition of aerobic rice were recorded with highest level of sulphur application@ $26 \mathrm{~kg} \mathrm{ha}^{-1}$. The two levels of S application varied significantly in their effect on nutrient composition of aerobic rice. The maximum nitrogen $(0.96 \%)$, phosphorous $(0.32 \%)$, potassium $(1.35 \%)$, calcium $(0.35 \%)$, magnesium $(0.21 \%)$ and sulphur $(0.33 \%)$ content of aerobic rice was recorded under RDF $+26 \mathrm{~kg}$ sulphur per hectare through ammonium sulphate $\left(\mathrm{T}_{6}\right.$ treatment).

\section{Introduction}

Rice is the staple food in Asia but also the single biggest user of fresh water. The declining availability of water threatens the traditional way of irrigated rice production. An efficient use of water is essential to safeguard food security in Asia. Aerobic rice is a new development in water saving technology, where rice is grown like any other upland cereal crop with supplementing irrigation. It is a system of growing high yielding rice in non-puddle and non-flooded aerobic soil. Sulphur is now recognized as fourth essential nutrient element after nitrogen, phosphorous, and potassium (Morris, 2007). Crop requires sulphur generally as much as phosphorous and one tenth of nitrogen. Its role in synthesis of certain amino acids such as cystine, cysteine, and methionine is well known. In sulphur deficient soil, the application of high rates of other nutrients $(\mathrm{N}$, $\mathrm{P}$ and $\mathrm{K}$ ) may not result in increased yields, due to imbalances in the $\mathrm{N} / \mathrm{S}$ and $\mathrm{P} / \mathrm{S}$ ratios in the plants. In addition, an adequate and balanced supply of nutrients favour the proper development of crops, with a positive impact on the yield (Fageria et al., 2011). The application of sulphur increases growth and yields in rice (Singh et al., 2012a, Jena and 
Kabi, 2012). Since paddy is one of the predominate crop in southern dry zone (zone 6) of Karnataka and continuous paddy growing has resulted in $S$ deficiency in command area of the zone. Hence a study was conducted to know effect of different sources and levels of sulphur application on plant nutrient content of aerobic rice.

\section{Materials and Methods}

A Field experiment was conducted at College of Agriculture, V.C. Farm, Mandya, Karnataka, during rainy season (Kharif) of 2015. It is located between $12^{0} 32^{\prime} \mathrm{N}$ latitude and $76^{\circ} 53^{\prime} \mathrm{E}$ longitude and 695 meters above mean sea level. The soil of the experimental field was red sandy loam in texture, neutral in reaction ( $\mathrm{pH} 7.4)$, Electrical conductivity was $0.14 \mathrm{dSm}^{-1}$ and organic carbon content was medium $\left(7.5 \mathrm{~g} \mathrm{~kg}^{-1}\right)$ medium in available nitrogen $\left(439 \mathrm{~kg} \mathrm{ha}^{-1}\right)$, phosphorus $(53.86 \mathrm{~kg}$ $\left.\mathrm{ha}^{-1}\right)$, available potassium (176.4 $\left.\mathrm{kg} \mathrm{ha}^{-1}\right)$ and with low available sulphur $\left(5.21 \mathrm{mg} \mathrm{kg}^{-1}\right)$.

The experiment was laid out in Randomized Complete Block Design (RCBD) with three replications. The treatments comprised of twelve treatment combinations consisting of five sources of sulphur fertilizers (viz. Gypsum, Ammonium Sulphate, Elemental Sulphur, 20:20:0:13 (Amophos) and SSP) and two levels of sulphur (13 and $26 \mathrm{~kg}$ Sulphur) $\mathrm{ha}^{-1}$ from each source along with one absolute control and recommend dose of fertilizers. Here 13 and $26 \mathrm{~kg} \mathrm{~S} \mathrm{ha}^{-1}$ was fixed mainly because the complex used in the experiment was 20:20:0:13 and based on $5 \mathrm{~kg} \mathrm{~S}$ acre ${ }^{-1}$ as standard was fixed. Recommended quantity of FYM at the rate of $10 \mathrm{t} \mathrm{ha}^{-1}$ was applied and mixed into the soil two weeks before sowing. As per the treatments fifty per cent of nitrogen was applied as basal dose and entire quantity of phosphorus, potassium, and sulphur were supplied at the time of sowing as a basal dose to each plot and remaining fifty per cent of nitrogen was applied as top dress at 30 days after sowing. The contribution of $\mathrm{N}$ and $\mathrm{P}$ from applied $\mathrm{S}$ sources viz., Ammonium sulphate and SSP was made good by reducing the quantity of fertilizer nutrient in respective treatment. High yielding early, medium duration rice variety Rashi seeds were sown in a well prepared leveled soil with $25 \mathrm{~cm} \times 25$ $\mathrm{cm}$, as inter and intra row spacing. Thinning and gap filling operations were done at 15 days after sowing and maintained optimum plant population. Irrigation was given as per requirement. Usually every 4 to 5 days once irrigation was given based on the moisture prevailing in the field as per the recommendation for aerobic rice to keep optimum moisture. Three hand weeding was done to keep the plots free from weeds at 30 , 45 and 60 DAS.

\section{Results and Discussion}

In general the $\mathrm{N}, \mathrm{P}, \mathrm{K}, \mathrm{Ca}, \mathrm{Mg}$ and $\mathrm{S}$ were increased due to the application of different sources and levels of sulphur application. The increase in nutrient content of aerobic rice from no sulphur application to either 13 or 26 $\mathrm{kg} \mathrm{S} \mathrm{ha}{ }^{-1}$ was found significant. Data presented in Table 1 indicates that the nutrient content of aerobic rice due to application of sulphur was influenced significantly. Significantly higher nitrogen, phosphorous and potassium content $(0.96,0.32$ and $1.35 \%$ respectively) was recorded under $\mathrm{RDF}+26 \mathrm{~kg}$ sulphur per hectare through ammonium sulphate $\left(\mathrm{T}_{6}\right.$ treatment $)$ followed by $\mathrm{T}_{12}$ treatment $(0.89,0.29 \& 1.28 \%$ respectively). However lowest nitrogen, phosphorous and potassium in plant sample was recorded under absolute control treatment $\mathrm{T}_{1}(0.65,0.29 \&$ $0.95 \%$ respectively). Significantly higher calcium content $(0.35 \%)$ was recorded under $\mathrm{RDF}+26 \mathrm{~kg}$ sulphur per hectare through ammonium sulphate ( $\mathrm{T}_{6}$ treatment) followed by $\mathrm{T}_{4}, \mathrm{~T}_{5}, \mathrm{~T}_{10}$ and $\mathrm{T}_{12}$ treatments $(0.27 \%$ each). 
Table.1 Effect of different sources and levels of sulphur on plant nutrient content (\%) of aerobic rice

\begin{tabular}{|c|c|c|c|c|c|c|}
\hline TREATMENTS & $\mathrm{N}(\%)$ & $\mathrm{P}(\%)$ & $\mathrm{K}(\%)$ & $\mathrm{Ca}(\%)$ & $\operatorname{Mg}(\%)$ & $\mathrm{S}(\%)$ \\
\hline $\mathbf{T}_{1}$ - Absolute control & 0.65 & 0.13 & 0.95 & 0.13 & 0.13 & 0.15 \\
\hline $\mathrm{T}_{2}-\mathrm{RDF}+\mathrm{FYM}$ & 0.77 & 0.20 & 1.07 & 0.16 & 0.16 & 0.19 \\
\hline$T_{3}-T_{2}+13$ kg S ha $^{-1}$ (Gypsum) & 0.82 & 0.21 & 1.11 & 0.21 & 0.17 & 0.21 \\
\hline $\mathrm{T}_{4}-\mathrm{T}_{2}+26 \mathrm{~kg} \mathrm{~S} \mathrm{ha}^{-1}$ (Gypsum) & 0.86 & 0.29 & 1.25 & 0.27 & 0.19 & 0.28 \\
\hline $\mathrm{T}_{5^{-}} \mathrm{T}_{2}+13 \mathrm{~kg} \mathrm{~S} \mathrm{ha}^{-1}$ (Ammonium sulphate) & 0.86 & 0.27 & 1.27 & 0.27 & 0.19 & 0.26 \\
\hline$T_{6}-T_{2}+26 \mathrm{~kg} \mathrm{~S} \mathrm{ha}^{-1}$ (Ammonium sulphate) & 0.96 & 0.32 & 1.35 & 0.35 & 0.21 & 0.33 \\
\hline $\mathrm{T}_{7}-\mathrm{T}_{2}+13 \mathrm{~kg} \mathrm{~S} \mathrm{ha}^{-1}$ (Elemental sulphur) & 0.79 & 0.25 & 1.14 & 0.19 & 0.16 & 0.26 \\
\hline$T_{8^{-}} T_{2}+26 \mathrm{~kg} \mathrm{~S} \mathrm{ha}^{-1}$ (Elemental sulphur) & 0.86 & 0.27 & 1.17 & 0.21 & 0.17 & 0.27 \\
\hline$T_{9-} T_{2}+13 \mathrm{~kg} \mathrm{~S} \mathrm{ha}^{-1}(20: 20: 0: 13)$ & 0.72 & 0.26 & 1.21 & 0.19 & 0.17 & 0.23 \\
\hline $\mathrm{T}_{10^{-}} \mathrm{T}_{2}+26 \mathrm{~kg} \mathrm{~S} \mathrm{ha}^{-1}(20: 20: 0: 13)$ & 0.79 & 0.27 & 1.24 & 0.27 & 0.19 & 0.25 \\
\hline$T_{11^{-}} T_{2}+13 \mathrm{~kg} S(\mathrm{SSP})$ & 0.84 & 0.25 & 1.24 & 0.21 & 0.17 & 0.27 \\
\hline$T_{12}-T_{2}+26 \mathrm{~kg} \mathrm{~S}(\mathrm{SSP})$ & 0.89 & 0.29 & 1.28 & 0.27 & 0.19 & 0.30 \\
\hline SEm \pm & 0.03 & 0.01 & 0.04 & 0.02 & 0.01 & 0.02 \\
\hline $\mathrm{CD}(\mathrm{p}=0.05)$ & 0.08 & 0.04 & 0.10 & 0.07 & 0.04 & 0.05 \\
\hline
\end{tabular}


However lowest calcium in plant sample was recorded under absolute control $\mathrm{T}_{1}$ $(0.13 \%) \cdot \mathrm{RDF}+26 \mathrm{~kg}$ sulphur per hectare through ammonium sulphate $\left(\mathrm{T}_{6}\right.$ treatment) recorded the highest magnesium in plant sample $(0.21 \%)$, followed by $\mathrm{T}_{4}, \mathrm{~T}_{5}, \mathrm{~T}_{10}$ and $\mathrm{T}_{12}$ treatments $(0.19 \%$ each $)$. Highest available sulphur was recorded $(0.33 \%)$ under $\mathrm{RDF}+26 \mathrm{~kg}$ sulphur per hectare through ammonium sulphate $\left(\mathrm{T}_{6}\right.$ treatment) followed by $\mathrm{T}_{12}$ treatment $(0.30 \%)$. However lowest exchangeable magnesium and available sulphur in plant sample was recorded under treatment $\mathrm{T}_{1}$ absolute control $(0.13$ and $0.15 \%)$.

The nitrogen, phosphorous and potassium content of paddy straw was much higher at 26 $\mathrm{kg} \mathrm{S} \mathrm{ha}{ }^{-1}$ and among the sources ammonium sulphate was superior over all other sources of sulphur. Nutrient content of aerobic rice increased significantly with increased sulphur application. Singh et al., (2012) also reported an increase in total $\mathrm{N}, \mathrm{P}$ and $\mathrm{K}$ concentration in paddy straw by increased with application of sulphur. Maximum NPK content was observed by application of $40 \mathrm{~kg} \mathrm{~S} \mathrm{ha}{ }^{-1}$. Fageria et al., (2011) also reported that $\mathrm{N}$ concentration was 8 per cent higher in plants fertilized with ammonium sulphate. Shivay et al., (2014) also reported that $\mathrm{N}$ concentration in paddy straw was highest with application of sulphur@ $45 \mathrm{~kg} \mathrm{ha}^{-1}$. Similar results were also reported by Rahman et al., (2007), Rahman et al., (2008), Rahman et al., (2009) and Habtegebrial et al., (2013).

The calcium, magnesium and sulphur content in paddy straw were also significantly influenced by sources and levels of sulphur application. The highest $\mathrm{Ca}, \mathrm{Mg}$ and sulphur content was recorded in $26 \mathrm{~kg} \mathrm{~S}^{-1} \mathrm{~s}^{-1}$ through ammonium sulphate and besides the forms, increased $\mathrm{S}$ application increased the $\mathrm{Ca} \mathrm{Mg}$ and sulphur content of paddy straw. Shivay et al., (2014) reported the similar results that increased sulphur application increased the sulphur concentration in paddy straw and highest sulphur concentration in paddy straw was obtained by application of $45 \mathrm{~kg} \mathrm{~S} \mathrm{ha}^{-1}$. Rahman et al., (2008) also reported increased sulphur concentration in paddy straw by application of sulphur at $20 \mathrm{~kg} \mathrm{ha}^{-1}$. This could be attributed to availability of nutrients in root zone of plants, where plants were able to utilize maximum nutrients. The superiority of ammonium sulphate over the other sources of sulphur is mainly due to the agronomic efficiency of the fertilizer. The research findings also proved that combined application of nitrogen with sulphur source in chemically bound form proved better compared to the individual application of nitrogen and sulphur to soil. Results of Fageria et al., (2011) also supporting for that ammonium sulphate as the most efficient source of fertilizer to paddy, which outperformed in all growth attributing characters of paddy by producing about 2 per cent higher plant height, 4 per cent higher shoot dry weight compared to urea as source of N. Further they reported that in upland rice maximum plant height was achieved at 260 $\mathrm{mg} \mathrm{N} \mathrm{kg}{ }^{-1}$ by ammonium sulphate.

\section{References}

Fageria, N.K., Moreira, A and Coelho, A.M., 2011, Yield and yield components of upland rice as influenced by nitrogen sources. J. plant nutrition., 34: 361-370.

Habtegebrial, K., Mersa, S., and Habtu, S., 2013, Nitrogen and Sulphur fertilizers effect on yield, nitrogen uptake and nitrogen use efficiency of upland rice variety on irrigated fulvisols of the Atar, Ethiopia. J. Soil Sci. Environ. mang., 4(3): 6266-6270.

Jena D and Kabi S. 2012. Effect of gromor sulphur bentonite sulphur pastilles on yield and nutrient uptake by hybrid rice potato-green gram cropping system in 
an Inceptisol. International Research Journal of Agricultural Science and Soil Science 2(5): 179-87.

Morris, R.J., 2007. Sulfur in agricultureinternational perspective. In Proceedings TSI/FAI/IFA workshop on sulfur in Balanced Fertilization. (R.K Tewatia, R.S. Choudhary, S.P. Kalwe Eds.), 4-6 October, 2006, (pp. 1-7). New Delhi: The Fertilizer Association of India.

Shivay, Y.S., Prasad, R. and Pal, M., 2014, Effect of levels and sources of sulphur and nitrogen concentration and uptake and S-use efficiency in Basmati Rice. Comm. Soil Sci. and Plt. Analysis. 45: 2468-2479.

Singh, A.K., Manibhushan, Meena. M.K. and Upadhyaya, A., 2012, Effect of sulphur and zinc on rice performance and nutrient dynamics in plants and soil of Indo gangetic plains. J. Agri. Sci. 4:162170.

Rahman, M.N., Islam, M.B., Sayem, S.M., Rahman, M.A. and Masud, M.M., 2007, Effect of different rates of sulphur on the yield and yield attributes of rice in old Brahmaputra floodplain soil. J. Soil. Nature., 1(1): 22-26.

Rahman, M.T., Jahiruddin, M., Humauan, M.R., Alam, M.J. and Khan A.A., 2008, Effect of sulphur and zinc on growth yield and nutrient uptake of boroice (cv. BRRI Dhan) 29. J. Soil. Nature, 2(3): 10-15.

Rahman, M.S., Ahmed, M.U., Rahman, M.M Islam, M.R. and Azafar, A., 2009, Effect of different levels of sulphur on the growth and yield of BRRI Dhan 41 . Bangladesh Res. Pub. J., 3(1): 846-852.

\section{How to cite this article:}

Sudhakara, N.R., N. Srinivasa and Krishnamurthy, R. 2018. Nutrient Composition of Aerobic Rice as Influenced by Different Sources and Levels of Sulphur Application. Int.J.Curr.Microbiol.App.Sci. 7(12): 2401-2405. doi: https://doi.org/10.20546/ijcmas.2018.712.272 